\title{
Erotyki niesamowite. \\ O Pamiątkach po lalce Hansa Bellmera ${ }^{1}$
}

\section{Jeremy Bell}

Trent University

\begin{abstract}
Urodzony w Niemczech surrealista, plastyk i pisarz Hans Bellmer jest dziś najbardziej znany jako autor dwóch lalek, które powstaty w Berlinie w latach 30. XX w., zachowaty się też zdjęcia i teksty na ich temat. Prace te wzbudzaja kontrowersje z uwagi na ich otwarcie erotyczny charakter $i$ wyzwania, jakie stawiaja widzom. Dlatego też były często krytykowane z perspektywy feministycznej. Jednak, jak udowadniam w niniejszym eseju, poczawszy od zorganizowanej niedawno w Berlinie wystawy "Podwójny Sexus", gdzie jego prace zostały wystawione obok twórczości Louise Bourgeois, wyraźnie widać, że Bellmer jest daleki od reifikowania norm ptci kulturowej; wręcz przeciwnie, dekonstruuje on stabilność męskiego ego.
\end{abstract}

Słowa kluczowe: Hans Bellmer, Louise Bourgeois, ciało, erotyka, lalka, męskość

\section{Podwójny Sexus}

Hans Bellmer nie wszystkim przypada do gustu. Niektórzy w obliczu jego prac czują się nieswojo; bywa nawet, że odczuwają lekkie obrzydzenie. Prawdę mówiąc, jego prace wprawiają wiele osób w zakłopotanie. Zetknięcie się z twórczością Bellmera można by porównać z odkryciem zbioru nieprzyzwoitych obrazków należących do naszych rodziców (wyblakłych zdjęć z Polaroidu czy serii zakładek na laptopie), gdyby nie fakt, że w przypadku Bellmera zdajemy sobie sprawę, o ile bardziej sprośne i perwersyjne są gusta naszych rodziców w porównaniu z naszymi własnymi. Jednak mimo iż prace Bellmera są prowokatorskie, pozostaje on jednym z najciekawszych i najbardziej kontrowersyjnych artystów XX w. Można wręcz powiedzieć, że jego twórczość jest „wypierana” wraz z pragnieniami przemocy i (de)sakralizacji, które wkradają się czasem do naszej fantazji. Bellmer traktuje takie wyobrażenia bardzo poważnie. Modernizm jest powszechnie uznawany za okrutną epokę, a u Bellmera okrucieństwo jest szczególnie widoczne. To właśnie ono nadaje jego twórczości niesamowity charakter. Ponieważ był wirtuozem BDSM i „perwersyjnych seksualności”, mimo upływu czasu jego prace nie straciły zdolności bulwersowania widzów. Prowokują długo po tym, jak "totalna rewolta" innych surrealistów została przetrawiona kulturowo i zawłaszczona ekonomicznie, jeżeli nie przed formalnym końcem surrealizmu w 1969 r., to w epoce późnego kapitalizmu, który kieruje się logiką wszystkożerności. Niewątpliwie właśnie dlatego feministki nadal krytykują Bellmera, widząc w nim mizogina czy artystę, który reifikuje falliczne normy.

\footnotetext{
${ }^{1}$ Angielska wersja artykułu Jeremy'ego Bella Uncanny Erotics - On Hans Bellmer's Souvenirs of the Doll ukazała się w czasopiśmie open access "Feral Feminisms: Feminist Un/pleasure: Reflections upon Perversity, BDSM and Desire" 2 (2014), gdzie dostępne są również ilustracje towarzyszące tekstowi. Polskie tłumaczenie publikujemy za zgodą autora i redakcji czasopisma. Tłum. Dominika Ferens i Tomasz Basiuk.
} 
Wystawa "Podwójny Sexus" zestawiła ze sobą prace Hansa Bellmera i Louise Bourgeois. Była to pierwsza specjalna wystawa zorganizowana przez Collection Scharf-Gerstenberg od momentu jej założenia w 2008 r. Prace można było oglądać od kwietnia do sierpnia 2010 r., po czym wystawa została przeniesiona do Gemeentemuseum w Hadze, a następnie do Galerii Whitechapel w Londynie. Udo Kittelmann, dyrektor berlińskiej Galerii Narodowej, zauważył we wstępie do "Hans Bellmer, Louise Bourgeois: Double Sexus", że od początku swojego istnienia Collection Scharf-Gerstenberg stara się przedstawiać „intymną i bardzo zróżnicowaną wizję Surrealizmu, a także prekursorów i następców tego ruchu”. Jest to "powściągliwa i introwertyczna kolekcja, przemawiająca do nas wyłącznie za pośrednictwem estetycznych walorów swoich dzieł sztuki, bez przegadanych komentarzy" (Kittelmann 2010: 13). Hans Bellmer to jeden z najważniejszych i najbardziej reprezentatywnych artystów dla Collection Scharf-Gerstenberg. Jako Niemiec żyjący poza krajem, we francuskojęzycznym środowisku, Bellmer reprezentuje zarówno zróżnicowaną wizję surrealizmu, do której aspiruje Collection Scharf-Gerstenberg, jak i estetykę introwersji i intymności. Jak pisze Kittelmann: „Jego małoformatowe fotografie i filigranowe grafiki tworzone na desce kreślarskiej są adresowane do uważnego widza, skłonnego do analizowania każdego detalu (Kittelmann 2010: 13).

Bellmer jest najbardziej znany dzięki lalce, którą zaczął tworzyć w Berlinie w 1933 r., i dwóm cyklom fotografii upozowanej lalki wykonanych w latach 1933-1939. Lecz te pamiątki lalki - i lalka jako temat - stanowiły jedynie początek jego pracowitej, czterdziestoletniej kariery, w trakcie której tworzył nie tylko zdjęcia, ale również ryciny i teksty. Na przykład w tekście z 1954 r., Petite anatomie de l'inconscient physique ou l'anatomie de l'image [Mała anatomia fizycznej nieświadomości, czyli anatomia obrazu], przechodzi od lalki do bardziej ogólnej teorii ciała, oraz do tego, co Bellmer nazywa "fizyczną nieświadomością".

By przedstawić klarowniejszy i bardziej precyzyjny obraz, powiedzmy: ciało jest podobne do zdania, które zaprasza cię do rozebrania go na części go, by je następnie składać w nieskończoną serię anagramów. (Bellmer 1954: 36)

Tym właśnie zajmuje się Bellmer, w sposób bezlitosny: po konstrukcji następuje dekonstrukcja i dezartykulacja, a wszystko to "w celu ponownego łączenia elementów" w niekończące się konfiguracje cielesności. Praca Bellmera ociera się między innymi o fetyszyzm, sadomasochizm i skopofilię. „Bellmer jest prorokiem nie tyle pożądania, co obsesji [...] seksu, szczególnie niezrealizowanych i nierealizowalnych implikacji seksu". Jego obsesja jest tak daleko posunięta, że skupia się na niemożliwym, gdyż jedynie niemożliwe mogłoby ją zadowolić" (Peppiatt 1973: 26). W tym sensie Bellmer wykracza poza to, co moglibyśmy w uproszczeniu nazwać "sztuką erotyczną". Fakt, iż Markiz de Sade i Georges Bataille obaj wywarli duży wpływ na całą twórczość Bellmera, stanowi testament przeciwstawnych sił pożądania z jednej strony, i wstydu i awersji z drugiej. Obraz pochodzący z drugiego cyklu fotografii reprezentuje tę właśnie tematykę (patrz Rys. 1). Erotyzm ciała lalki, jednocześnie dziecinnego i obrzmiałego, z twarzą przysłoniętą przegubami kulowymi przypominającymi piersi, podkreśla czarne oparcie krzesła, blond peruka i wstążka. Widzimy ciało złożone z nagich, mechanicznych części, które, choć pozornie jest kompletne, wyraźnie posiada dwie miednice. Widok ten niepokoi, lecz jego znaczenie jest trudne do uchwycenia. Tak jak większość prac Bellmera, w których małe dziewczynki, lalki i inne zabawki są penetrowane, rozkrawane, lub zobrazowane 
w stanie rozkładu, jak w koszmarach czy stłumionych wspomnieniach z dzieciństwa, ta praca ewidentnie wyraża ciemną, przerażającą stronę surrealizmu.

Dlatego zestawienie Ballmera z Louise Bourgeois jest pouczające. Artystów tych łączą te same motywy - lalka i "hermafrodyta”, dodatkowe tułowia i kończyny - ale również temat rozczłonkowania ciała, jego bezbronności czy buntu. Kuratorka Collection Scharf-Gerstenberg, Kyllikki Zacharias, zauważa, że powiązania między Bellmerem i Bourgeois nie są do końca przypadkowe. Mieli podobne życiorysy, oboje spędzili większość życia z dala od rodzinnych krajów. Bourgeois przeprowadziła się z Francji do Stanów Zjednoczonych w 1938 r., a Bellmer opuścił Niemcy na zawsze w 1939 r. Ponadto, oboje postrzegali odrzucenie przez swoich ojców jako problem, z którym zmagali się w swojej pracy. Oboje wciągają nas w przeszłość, w świat dziecięcej, polimorficznej perwersyjności. Stawiają opór nie tylko własnym ojcom, ale również, jak pisze Zacharias, "systemowi ojca”. Według Zacharias, „Erotyczne tematy oraz fizyczne i seksualne formy wyjątkowo nadają się do wyrażania buntu przeciwko figurze ojca, znakomicie można przełamywać tabu za pomocą hybryd seksualnych" (29). Podobną myśl wyraziła Alyce Mahon w odniesieniu do surrealizmu jako takiego, a mianowicie uznała, że po 1930 r. surrealizm uosabiał „politykę Erosu” (Mahon 2005: 9-21).

Wystawa "Podwójny Sexus" została zaaranżowana tematycznie wokół Historii oka Bataille'a (1928) i Diany z Efezu; towarzyszyły jej wybrane fragmenty z autobiograficznej powieści Sexus Henry'ego Millera i niepublikowanego tekstu Elfriede Jelinek, Ciało i kobieta (Klaudia). Gdy oglądamy je razem, staje się oczywiste, że Collection Scharf-Gerstenberg otwarcie kultywuje "politykę Erosu". W tekście Powitanie towarzyszącym wystawie Christina Weiss dziękuje Udo Kittelmannowi i Killikki Zacharias za wsparcie, które "kładzie szczególny - erotyczny - akcent w obrębie "surrealistycznego świata«" (Kittelmann i Zacharias 2010: 23). Od skopofilskiej precyzji Bellmera po amorficzną, macierzyńską zmysłowość Bourgeois, oraz od konfrontacyjności Jelinek po komiczną skatologię Millera - wszędzie napotykamy na wyzywający erotyzm. Wywołuje on istotne z punktu widzenia historii sztuki pytania o surrealizm, jego kontekst i spuściznę, ale również pytania bardziej osobiste. Jak powinniśmy reagować na ten typ niepokojącej metaforyki? Przyjrzyjmy się rzeźbie zatytułowanej „Kobieta" Bourgeois z 2005 r., ukazującej głowę i tors wykonane z tkaniny, połączone z dwiema formami przypominającymi piersi, leżącymi na poduszce pod szklanym kloszem. Figura ta jest typowa dla jej twórczości. Pozbawiona kończyn postać nie może wyrwać się z potrzasku, ponadto, jej proste, otwarte oczy i usta sugerują krzyk, który nie dociera jednak do nas spod szkła. Tak jak w przypadku lalki Bellmera, zdecydowanie dzieje się tu coś przerażającego.

Wpływ Bataille'a na Bourgeois i Bellmera jest niezaprzeczalny. Widać go w „Maladie de l'amour (\#2, \#3)" Bourgeois (2008), składającej się z serii naszkicowanych fallicznych figur. Z ich czubków zerkają maleńkie błękitne oczka przypominające oczy księdza w kulminacyjnym momencie Historii oka (którego bohaterowie gwałcą, mordują i kastrują). W przypadku Bellmera wpływ jest bardziej bezpośredni. Bellmer spotkał Bataille'a w 1945 r. za pośrednictwem wydawcy, Alaina Gheerbranta, który poprosił Bellmera o zilustrowanie nowego wydania Historii oka. Wpływ Bataille'a na Bellmera widać w rysunkach, rycinach i fotografiach, także w tych stworzonych później do Madame Edwarda. "Zgadzam się z Georgesem Bataillem”, tłumaczył później Bellmer, „że erotyzm związany jest z wiedzą o złu i nieuchronności śmierci[,] nie jest on spontaniczną ekspresją radosnej pasji" (cyt. za Webb 1975: 369). Ale Bellmer inspirował również Bataille'a, którego koncepcja Erosa pojmowanego 
jako seksualność z góry skażona grzechem i świadomością śmierci - jedyna możliwa koncepcja w obliczu śmierci czy nieobecności Boga, jest analogią wizji wypracowanej przez Bellmera. „W rzeczywistości", pisze Bataille w Erotyzmie (1957), "domena erotyzmu to domena przemocy, gwałtu" (Bataille 1986: 16). A to, co widzimy u Bellmera to właśnie gwałt, pojawia się w "stłumionych dziewczęcych myślach", które chowa w niedokończonej panoramie brzucha pierwszej lalki, ale również w końcowej serii rycin, "Petit traité de morale” (1968), dotyczących tajemnic katolickiego konfesjonału i de Sade'a. Podobną wrażliwość znajdziemy u Bourgeois, ale przede wszystkim u Elfriede Jelinek, kontrowersyjnej noblistki piszącej wprost o walce płci i seksualnym wykorzystywaniu kobiet. Bellmer również zdaje się traktować kobiecą seksualność instrumentalnie. Ale w tym, co robi, zbliża się do Millera, ponieważ wykorzystywanie to jest bardzo męskie i zorientowane heteroseksualnie. Lalka i jego inne prace są niezaprzeczalnie dziełem mężczyzny. Wykonane 60 lat później erotyczne lalki Cindy Sherman, inspirowane bezpośrednio pracami Bellmera i przedstawieniami kończyn Roberta Gobera (pośrednio inspirowanymi twórczością Bellmera), są przejawem znacznie bardziej ambiwalentnych seksualności. Owej ambiwalencji nie usuwa to, że u Bellmera motywy perwersji i bluźnierstwa, choć już nie okrucieństwa, bynajmniej nie powielają status quo.

Nasuwa się więc pytanie: czy podstawową różnicą pomiędzy Bellmerem i Bourgeois jest różnica płci biologicznej? Poprzez „różnicę” nie mam na myśli jedynie opozycji pomiędzy płciami ale i różnicę związaną ze stosunkiem do enigmatycznych form, takich jak fallus, srom, androgyne i tym podobne. Rzeczywiście zarówno dla Bellmera jak i dla Bourgeois różnica płciowa wydaje się stanowić problem, źródło napięć różniących ich od siebie, a także teren poszukiwań artystycznych. Jak stwierdzają kuratorzy wystawy "Podwójny Sexus”, Bellmer i Bourgeois zaabsorbowani są tymi różnicami nawet wtedy, gdy starają się je przezwyciężyć. Podważając proste różnice anatomiczne, jak również zbudowane na nich hierarchie społeczne, ich prace dążą do unaocznienia płciowej hybrydy. Nawet gdy uznają istnienie podziału między płciami, starają się go przekraczać, z męskości do kobiecości i z powrotem, z fantazji do lęku i z powrotem. Wszystko to odnajdujemy w namacalnym erotyzmie Bellmera i Bourgeois. Namacalny erotyzm jest tylko częścią tego, co sprawia, że wystawa "Podwójny Sexus" jest tak ciekawa. Nawet jeżeli Bellmer i Bourgeois kwestionują nasze rozumienie tożsamości i binarnych podziałów ja/inny, męskie/kobiece, piękne/ groteskowe, musimy zapytać, czy Bellmer replikuje "męskie spojrzenie" [male gaze] czy je przełamuje? Warto zacząć odpowiedź na to pytanie od Pamiątki po lalce, eseju Bellmera otwierającego Die Puppe, który pozwala dostrzec korelacje pomiędzy perwersją, fetyszyzmem i polimorficznym ciałem wjego pracy, i zrozumieć ich ogólne miejsce w sferze wizualnej².

\section{Pamiątki dotyczące lalki: wariacje na przegubową nieletnią}

Dopasuj główkę do panewki, wypróbuj przeguby kulowe, wyginając je do oporu w dziecinnej pozie, ostrożnie wymacaj zagłębienia - dotykanie ich wklęstości sprawia przyjemność, zatrać się w muszli ucha, tworząc piękno, ale i mściwie rozprowadź sól znieksztatcenia. Nie zatrzymuj się na powierzchni, obnaż dziewczęce myśli, aż odsłoni się tło, z którego się wyłaniaja, najlepiej przez pępek, który jawi się

\footnotetext{
2 Podczas gdy Therese Lichtenstein tłumaczy tytuł wstępnego eseju Bellmera do Lalki jako Wspomnienia na temat lalki [Memories of the Doll Theme], ja tłumaczę go jako Pamiątki po lalce [Souvenirs of the Doll]. Tytuł francuski brzmi Souvenirs relatifs à la poupée. Jestem wdzięczny Lichtenstein za tłumaczenie tekstu, z którego tu korzystam. Pozwoliłem sobie tylko zmienić jego tytuł.
} 
jako kolorowa panorama podświetlona elektrycznościa głęboko w brzuchu. Czyż nie takie powinno być rozwiąanie?

Hans Bellmer, Souvenirs Relative to the Doll [Pamiątki dotyczące lalki]

Niedostępna, ponieważ wszystko, co o niej, zamkniętej, można powiedzieć, to granica najmniejszej przestrzeni najwęższego widoku, w wyrachowaniu i w kłótni, wykłócając się i kalkulując, próbujemy odnaleźć wtasne serce i ocenić wiarę w dzieciństwo.

Paul Eluard, Les jeux de la poupée [Gry lalki]

Czymże są te pamiątki i jak się maja do lalki? W uproszczeniu, są to dwa cykle fotografii wykonanych przez Bellmera w latach 1933-1939 i powiązane z nimi teksty. Tematem pierwszego cyklu, składającego się głównie ze zbliżeń, jest konstrukcja. Na jednym ze zdjęć rozłożone części lalki widać z lotu ptaka (Rys. 2). Ułożona w pionie noga stanowi ramę dla tułowia, dłoni, stóp, dwóch szklanych oczu i kilku piór. Uważnie zaaranżowane części tworzą efekt całkowicie zdezartykułowanego tableau, bez cienia życia. Na innym zdjęciu stojąca lalka zdaje się pozować do portretu (Rys. 3). Widziana od tyłu, przytulona do ściany, ma na głowie czarną perukę i jest odziana w białą koszulkę. Koszulka jest uniesiona do pasa. Lalka zerka za siebie przez ramię, jakby uwodzicielsko. "Spojrzenie" lalki kontrastuje z gipsową twarzą bez wyrazu i pustymi oczodołami. Nieśmiała filuterność łączy się tu z ruiną, lalka będąca przedmiotem pożądania jednocześnie jest martwym fetyszem. Należy zwrócić uwagę na wieloznaczny status obrazu jako medium, mamy tu do czynienia z fotografią, rzeźbą i tekstem. Wymięta pościel i koronki, hula-hop i marmur, oparcie krzesła i róża na długiej łodydze wraz z butem na wysokim obcasie inicjują dziwną historię na temat składania i destrukcji lalki - rodzaj fotograficznego pamiętnika perwersji, różnicy płci i odsuniętych, lecz nawiedzających narracji.

„Na co ja patrzę?" To jedno z wielu pytań zadawanych widzowi przez lalkę. Ma ona szkielet z kijów od miotły i metalowych prętów, dłoń i dwie stopy wyrzeźbione z drewna, tułów i głowę z gipsu, kilka peruk, buty i pończochy, a także inne ubrania i rekwizyty, przez co właściwie nie można jej uznać za jednostkowe albo jednolite ciało. W rzeczywistości były dwie lalki. Bellmer wykonał 30 zdjęć pierwszej, nad którą pracował od 1933 do 1934 r. Czternaście z nich posłużyło za ilustracje do wydanej prywatnie w 1934 r. książeczki Die Puppe [Lalka]. Po tym, jak Bellmer zetknął się z surrealistami, wszystkie te fotografie zostały przedrukowane wraz z czterema wcześniej niepublikowanymi na dwóch stronach szóstego numeru "Minotaura", pod tytułem La Poupée: Variations le montage d'une mineure articulée [Lalka. Wariacje na temat montażu przegubowej nieletniej]. W siódmym numerze "Minotaura" ukazały się kolejne zdjęcia lalki, tym razem jako ilustracje do wiersza Appliquée [Aplikacja] Paula Eluarda, zainspirowanego lalką. W czerwcu 1936 r. Die Puppe ukazała się we francuskim tłumaczeniu Roberta Valançay pod tytułem La Poupée. Wtedy też Bellmer zaczął konstruować swoją drugą, bardziej skomplikowaną lalkę, której kluczowym elementem był centralny przegub kulowy. Między 1935 a 1939 r. fotografował ją ponad sto razy. Piętnaście z tych zdjęć stanowiło oprawę czternastu wierszy Eluarda i Notatek na temat przegubu kulowego Bellmera w ksiażce Les Jeux de la poupée [Gry lalki]. Choć książka ta powstała już w 1939 r., głównie za sprawą II Wojny Światowej nie została opublikowana do 1949 r. 
Głowa, dłonie i nogi pierwszej lalki zostały wykorzystane do budowy drugiej, ale Bellmer stworzył dodatkowe nogi, ramiona, tułowie, miednice i piersi. Nieporozumieniem jest więc mówienie o tych lalkach jako o zunifikowanych ciałach. Bardziej przypominają one to, co Freud opisuje jako polimorficznie perwersyjne dziecko, czy fragmentaryczne, niewyartykułowane kanały przyjemności, które nie są ani pojedyncze, ani mnogie. Dlatego można powiedzieć, że lalka uosabia całą gamę cielesnych rzeczywistości. Lalka jest jak dziecko autoerotycznie ssące kciuk i pocierające genitalia w trakcie oddawania moczu, które, jak pisze Freud w Trzech rozprawach z teorii seksualności, "można nakłonić do wszelkich rodzajów transgresji" (Freud 167). Bellmer jest właśnie uwodzicielem lalki.

W tekście Wspomnienia na temat lalki Bellmer przedstawia nam metodologię, którą wypracował na tym wczesnym etapie. Kreśląc analogie pomiędzy "małymi dziewczynkami” a innymi rzeczami ze swojego dzieciństwa, stwierdza, iż "pewne rzeczy w świecie małych dziewczynek zawsze były obiektem pożądania" (Bellmer 2001: 171). Zwraca uwagę na delikatność i pewnego rodzaju nieosiągalność tych rzeczy: "Często są to rzeczy kruche, takie jak jajka wielkanocne udekorowane gołąbkami i pierścieniami z różowego cukru, które poza tym, że kusiły, nie posiadały żadnych walorów" (Bellmer 2001: 171). W tym sensie pamiątki są świadomie traktowane w sposób fetyszystyczny, przynajmniej z punktu widzenia psychoanalizy. Jak pisze Bellmer, „ludzie tacy jak ja niechętnie przyznają, że to właśnie te rzeczy, o których nic nie wiemy, zapadają nam aż za bardzo w pamięć" (Bellmer 2001: 172). A jaki to "obiekt" bardziej zapada w pamięć niż matczyny fallus? Freud pisze w „Fetyszyzmie": „fetysz jest substytutem kobiecego (matczynego) fallusa, w który mały chłopiec kiedyś wierzył i którego - z dobrze nam znanych przyczyn - nie chce się wyzbyć" (96). Te dobrze nam znane przyczyny to traumy związane z rozwojem płciowym, dochodzenie do świadomości różnicy płci i najważniejsza - „kompleks kastracji". Według Freuda fetyszysta "jednocześnie zachowuje wiarę w matczyny fallus i wyrzeka się jej. Wobec konfliktu między siłą niechcianej obserwacji a intensywną awersją wobec niej osiągnięty zostaje kompromis, jaki możliwy jest tylko na mocy praw myśli nieświadomej, czyli w procesach pierwotnych" (Freud 2005: 96). Fetysz jest więc właśnie kompromisem. Wahając się pomiędzy fantazją i rzeczywistością zachowuje się jak substytut matczynego fallusa, dzięki czemu pozostaje obecny w swojej nieobecności.

Pamiątki po lalce Bellmera, cechujące się zarówno nadmiarem znaczeń, jak i pustym, martwym środkiem, zarówno nie-obecnością [manque-à-être] jak i punktem skupienia fiksacji, są porównywalne do matczynego fallusa. Ich ambiwalencji trudno nie zauważyć. Przybierając równocześnie postać fotografii, rzeźb i tekstów, a także przedmiotów erotycznych i znaków, pamiątki te nadają lalce niesamowity charakter zawieszony pomiędzy kobiecą osobowością a martwym przedmiotem. Bellmer czerpał z tych samych źródeł, na podstawie których Freud wypracował swoją koncepcję niesamowitości w eseju Niesamowitość z 1919 r. Obaj myśleli o lalkach i marionetkach w niemieckiej romantycznej literaturze i kulturze. Freud i Bellmer pracowali więc obok siebie. Rosalind Krauss pisze o fotografiach lalek Bellmera: „Nic nie naświetla całej tej serii, odgrywającej w nieskończoność proces konstruowania i rozczłonkowywania - czy też konstruowania jako rozczłonkowania - tak dobrze jak analiza [noweli E.T.A. Hoffmana] Piaskun" (86). Freud również pokazuje, że można dostrzec cenne powiązania między somatycznymi i semantycznymi aspektami niesamowitości. W sensie etymologicznym, das Unheimlich (niemiecki ekwiwalent niesamowitości) pozostaje w strukturalnej relacji ze swoim językowym antonimem das Heimlich, który tłumaczy się jako "znajomy”, ale również jako "skryty". Niesamowite będzie "to, co zostało wyparte, a teraz powraca" (Freud 
2005: 147). Z drugiej strony, jak to ujął Friedrich Schelling, "niesamowite jest to, co nazywa się tym wszystkim, co miało pozostać sekretne i ukryte, a teraz wyszło na jaw" (Schelling cyt. za Freud 2005: 132). Freud ilustruje tę myśl w analizie noweli Hoffmana o Natanielu, który popada w szaleństwo, gdy powracają traumy z dzieciństwa, ale również z powodu swojej irracjonalnej miłości do Olimpii, lalki wielkości kobiety, którą przypadkowo bierze za prawdziwą osobę. Freud niemal zupełnie pomija tę część opowiadania, jakby "wypierał" efekt niesamowitości wywoływany przez Olimpię. Zauroczony przez Olimpię Nataniel podgląda ją z ukrycia. Gdy przychodzi prosić o jej rękę, przypadkowo staje się świadkiem awantury z udziałem twórcy Olimpii, Profesora Spalizini i Coppoli o to, do którego z nich należą jej oczy. Wtedy dopiero Nathaniel uświadamia sobie swój błąd, ale nie powstrzymuje go to od samobójczego skoku na końcu opowiadania. Niepokojąca wątpliwość opisana przez Freuda jest tym samym niepokojem, który wywołują pamiątki Bellmera.

Z lalką związany jest mit początku. Sam Bellmera twierdził, że inspiracją były trzy wydarzenia, które miały miejsce niemal równocześnie. Najpierw otrzymał od matki pudło pełne zepsutych lalek, czasopism ilustrowanych linorytami, szklanych kulek, przebrań i innych rzeczy związanych ze swoim dzieciństwem. Mniej więcej w tym samym czasie jego rodzina przeprowadziła się z Karlsruhe do Berlina. Bellmer ponownie nawiązał kontakt ze swoją młodszą kuzynką, Ursulą Naguschewski, która była obiektem jego erotycznych ciągot od czasów wspólnie spędzonej młodości. Teraz, gdy kuzynka znów była w pobliżu, ale już jako niezależna młoda kobieta, Bellmer zaczyna powracać do swoich młodzieńczych fantazji. Ale dopiero w 1932 r. - gdy obejrzał wystawioną przez Maxa Reinhardta opere „powieści Hoffmana - nadeszła prawdziwa inspiracja dla lalki. Bellmer później opowie, jak zafascynowany i jednocześnie przerażony oglądał koniec Aktu I, gdy Olimpia jest rozczłonkowywana (Webb i Short 2006: 20-22).

Inspirację tą sceną widzimy w innym obrazie z Lalki, w którym lalka, rozebrana na części, jest sfotografowana z lotu ptaka na pasiastym materacu (Rys. 4). Jej głowa leży obok tułowia, kończyn, szklanego oka i ciemnej peruki. Biegnące po przekątnej paski materaca pod lalką i jej łysa głowa uwypuklają fakturę jej brzucha i nieowłosionego łona. Widziana na przemian jako fetysz, uwodzicielka i ofiara, lalka wywołuje u widza złożony efekt emocjonalny, coś pomiędzy fascynacją, obrzydzeniem i niepokojem. Prawdopodobnie dlatego Hal Foster w Compulsive Beauty [Kompulsywne piękno] posługuje się marcusiańskim pojęciem "desublimacji” w odniesieniu do Bellmera. W meandrach kastrujących i fetyszystycznych form Foster dopatruje się uwalniania wypartych niemowlęcych popędów. "Klarowniej niż jakikolwiek inny surrealista”, tłumaczy Foster, „Bellmer ilustruje napięcie pomiędzy wiązaniem a rozbijaniem, a także oscylację pomiędzy sadyzmem i masochizmem, tak charakterystyczną dla surrealizmu" (Foster 1993: 107).

Sposób, w jaki Bellmer, jako jeden z surrealistów, posługuje się niesamowitością (unheimliche) wcale nie jest oczywisty. Gdy w 1925 r. surrealizm był w fazie wschodzącej, Bellmer wybrał się po raz pierwszy w podróż do Paryża. Nie znał jeszcze prac Bretona i innych surrealistów. Bretona i całą resztę spotkał dopiero za drugim razem, po tym, jak jego tekst ukazał się w "Minotaurze". Robert Short spekuluje jednak, że proliferacja automatów i manekinów w surrealizmie tego okresu, tuż po kontaktach surrealistów z Bellmerem, sugeruje, iż wywarł on na nich wpływ. Short zwraca szczególną uwagę na Międzynarodową Wystawę Surrealistyczną z 1938 r., w ramach której zdjęcia lalki Bellmera sąsiadowały z manekinami ubranymi przez Maxa Ernsta, Joan Miró, Mana Raya, Marcela 
Duchampa, Salvadora Dalí, André Massona i innych. Lalka Bellmera stanowiła w tym otoczeniu "archetypiczny obiekt surrealistyczny" (Webb i Short 2006: 35).

Ta na pozór niewinna zabawka, uprowadzona z chronionej przestrzeni pokoju dziecięcego, została zamieniona w krzykliwy fetysz wzbudzający wieloznaczne, niemożliwe do wypowiedzenia, lecz namacalne erotyczne pożądanie. Żaden surrealistyczny obiekt nie zawiera w sobie tylu zagadek - nie tylko tych, o których pisał Hoffman, dotyczących różnicy między naturalnym i sztucznym, żywym i martwym, ale nowych bellmerowskich zagadek dotyczących dzieciństwa i kobiecości, pomiędzy którymi zawieszona jest lalka. Bellmer zawarł w tych pracach wiedzę na temat przedwcześnie dojrzałej seksualności dziecka, już wcześniej obszernie udokumentowanej przez Freuda, ale też ślady dziecięcej wyobraźni i tęsknot w psychice dorosłych (Webb i Short 2006: 35).

Ale wpływ był niewątpliwie obopólny. Tuż po powrocie do Berlina Bellmer rozpoczął prace nad drugą lalką. Była ona bardziej skomplikowana od swojej poprzedniczki, częściowo w reakcji na entuzjastyczną recepcję jego prac przez innych surrealistów. W tym okresie Bellmer zaczyna przenosić lalkę ze stosunkowo zamkniętej przestrzeni swojego mieszkania między innymi do pobliskiego lasu, na klatkę schodową, do piwnicy i na stóg siana. Zaczyna też tworzyć kompozycje z dwoma tułowiami, a także z dwoma parami nóg sterczących z przeciwległych końców tułowia. „Ta gra należy do kategorii »poezji eksperymentalnej«", pisze we wstępie do drugiego cyklu fotografii lalek. „Jeżeli pamięta się o kluczowej metodzie prowokacji w grze, to zabawka będzie jawić się jako prowokacyjny obiekt" (Bellmer 2000: 212). Podejmując w coraz bardziej wyzywający sposób temat perwersji i skandalu, które w pierwszym cyklu były jedynie zasugerowane, poszerzał swój repertuar o surrealistyczną koncepcję prowokacyjnej zabawki jako poezji eksperymentalnej.

Na tym polega skandal lalki, tym bardziej skandalicznej ponieważ odzwierciedlała to, co Rosalind Krauss nazywa skandalem surrealistycznej fotografii, czyli jej skandalicznej "fetyszyzacji rzeczywistości”, negującej różnicę pomiędzy "naturalnym” a „wymyślonym” (Kraus 1985: 69). Jak tłumaczy Krauss, fetyszyzm nie tylko Bellmera ale surrealistycznej fotografii jako takiej opiera się na zaprzeczeniu, że "naturalne” istnieje - zaprzeczeniu wynikającemu z różnicy płciowej. Pisze ona, że „jeżeli fetyszyzm polega na podstawieniu tego, co nienaturalne w miejscu naturalnego, to zasadza się on na odmowie akceptacji różnicy płci" (Krauss 1985: 71). Według Krauss, właśnie tak surrealistyczna fotografia fabrykuje rzeczywistość. Lecz zaprzeczenie, o którym mowa powyżej jest niejednorodne. Jak zauważa Hal Foster, niekiedy w ramach surrealizmu - na przykład u Bellmera - piętrzą się formy kastracyjne i fetyszystyczne. W innych przypadkach formy kastracyjne są wypierane. „Pod tym względem lalki mogą przekraczać (czy może sprawować sadystyczną potrzebę kontroli), aż do momentu, w którym męski podmiot zmierzy się ze swym największym lękiem - przed rozczłonkowaniem, utratą integralności i rozpadem" (Foster 1991: 94). Biorąc to pod uwagę Foster sądzi, że to, co u Bellmera najbardziej perwersyjne i sadystyczne jest właśnie tym, co stawia go po stronie kobiecości, płynności a w efekcie w opozycji do „porządku fallicznego. 


\section{Seksualność jest „Artylerzystką w stanie łaski”}

W tekście Petite anatomie de l'inconscient physique ou l'anatomie de l'image z 1954 r., opisującym to, co Bellmer postrzega jako fizjologiczne parametry pożądania i erotyzmu, powraca on do spostrzeżeń Freuda odnośnie przemieszczeń i kondensacji zachodzących pomiędzy językiem a rzeczywistością materialną. Bellmer zwraca tu uwagę na dokonujące się między nimi podmiany, na ich wzajemną zwrotność i wymienność. Obserwując ból zęba, który powoduje skurcz dłoni i palców, Bellmer ponownie dostrzega migrację centrum podniecenia w przypadku nastolatki badanej przez Lombroso, która wraz z początkiem menstruacji i związanymi z nią atakami histerii ilunatyzmu, utraciła wzrok, lecz widziała nadal poprzez nos i lewą małżowinę uszną. To samo dostrzega u innej dziewczyny, która w sposób histeryczny przemieściła projekcje swoich genitaliów na oko, ucho i nos. Dla Bellmera jest to coś więcej niż synestezja, doświadczenia te ilustrują „przedziwne połączenie tego, co jednocześnie 'prawdziwe' i 'wirtualne', 'dopuszczalne' i 'zakazane', które pozwala komponentom jednej strony dychotomii zdobyć to, co druga strona dychotomii w pewnym sensie oddaje" (Bellmer 2004: 8). To właśnie w tym tekście odsłania fetyszystyczny aspekt swojej twórczości.

Do chwili obecnej nikt poważnie nie zastanawiał się nad tym, na ile obraz pożądanej kobiety jest z góry zdeterminowany przez obraz pożądającego ją mężczyzny. Proces ten składa się z serii projekcji fallicznych, które stopniowo przechodzą od elementu kobiety do całości w taki sposób, ze palec kobiety, jej dłoń, ręka czy noga staje się narządem seksualnym mężczyzny. Tym sposobem narząd płciowy mężczyzny może być nogą kobiety w ciasnej pończosze przesłaniającej nabrzmiałe udo, czy też para zaokrąglonych pośladków podkreślających nieco wygiętą linię kręgosłupa (Bellmer 2004: 25).

Między myślą Bellmera i Lacana znajdziemy wiele paraleli, szczególnie w tekście Znaczenie fallusa. Jak to ujął Lacan, używając własnej terminologii, "fallus jest znaczącym, którego funkcja w intrasubiektywnej ekonomii analizy może unieść zasłonę z funkcji, którą pełnił w misteriach. Bowiem to fallus jest znaczącym przeznaczonym do oznaczania efektów znaczenia w ogóle, o ile znaczący warunkuje je poprzez swoją obecność jako znaczący" (Lacan 2006: 579). Fakt, iż Bellmer nie posługuje się terminologią „sygnifikacji” Saussure'a, nie powinien przesłaniać nam analogii. Trzeba zastanowić się nad rolą metonimii i przenośni w bellmerowskim ciele-jako-anagramie. Paralele pomiędzy Bellmerem i Lacanem też nie są przypadkowe. Ponieważ obaj publikowali swoje wczesne prace w czasopiśmie "Minotaur" Alberta Skiry, jest prawdopodobne, że zainteresowania Bellmera i Lacana relacją pomiędzy językiem a erogennym ciałem były pochodną zarówno ich przyjaźni, jak i z pytań wynikających z ducha epoki. Wymowne są komentarze Shorta na temat recepcji Petite anatomie [Małej anatomii] Bellmera w 1954 r.:

Sam Breton, mimo wiecznych zastrzeżeń do Bellmera, natychmiast przesłał mu gratulacje pocztą pneumatyczną. Psychiatra Jacques Lacan nie krył swojego entuzjazmu, a stary znajomy Bellmera, dr [Gaston] Ferdière, zwięźle wyraził swoją aprobatę słowami »Tak jest«. [it's correct]. Ale najstosowniejsze powitanie książki nadeszło ze strony Mana Raya, który przesłał Bellmerowi anagram "Image-Magie" [obraz-magia]. (Webb i Short 2006: 121) 
Jeżeli chodzi o zbieżność pomiędzy twórczością Bellmera a wyłaniającymi się formami surrealistycznego erotyzmu, to miejsce tej twórczości jest na przecięciu transgresji, reprezentacji i ludzkiego ciała. Mahon pisze na temat Międzynarodowej Wystawy Surrealistycznej z 1959 r. dedykowanej Erosowi, a szczególnie jego ciemniejszemu elementowi wywodzącemu się od de Sade'a: „najlepsze miejsce zarezerwowano tu dla Lalki Hansa Bellmera, zwisającej z sufitu jak ofiara de Sade'a, jej ciało tak wystylizowane i powykręcane, że wyglądało jak dwunożny potwór, z którego formą kontrastowały dwie pary dziewczęcych trzewików i skarpet oraz pusty wyraz twarzy" (Mahon 2005: 159). Konfigurację tę zaprezentowano obok pracy kanadyjskiej surrealistki Mimi Parent, "MasculineFeminine": "krawat wykonany z kobiecych włosów spina kołnierz białej koszuli i wyłogi czarnej marynarki". Zdjęcie tej pracy wykorzystano na zaproszeniu na wystawę. Jak zauważa Mahon, „włosy były seksualnie sugestywne, ale jednocześnie makabryczne, nasuwające na myśl skalp czy coś w rodzaju trofeum" (Mahon 2005: 152). Jeżeli fetyszyzm nie jest w tych pracach dosłowny, to na pewno jest zamierzony - zamierzony i oparty na (być może niekiedy nieświadomym) zaprzeczeniu różnicy płci.

Czy Bellmer pracuje w obrębie rejestru fallicznego, czy nie? Pytanie to należałoby zadać w odniesieniu do całej międzywojennej awangardy, czyli dada i surrealizmu, ale też jej literackich antenatów, takich jak de Sade, Beaudelaire i Lautréamont. Pytanie to jest szczególnie istotne w przypadku Bellmera z uwagi na jego długotrwałą i poważną fascynację erotyzmem. Można by nawet uznać tę tematykę za główną stawkę jego pracy, czy też pewnego rodzaju ryzykowny zakład o wartość perwersji, ale też o wagę, jaką niesie taka wartość. "Chciałem pomóc ludziom pozbyć się swoich kompleksów”, tłumaczył później, "by mogli pogodzić się ze swymi instynktami, tak jak sam usiłowałem to robić. Pewnie chciałem, by ludzie naprawdę doświadczali swych ciał - a wydaje mi się, że to jest możliwe jedynie przez seks" (cyt. za Webb 1975: 370). Nic dziwnego, że twórczość Bellmera jest dla widza poważnym wyzwaniem.

To wyzwanie jest powodem, dla którego Krauss i Foster stwierdzają, iż "mylą się ci, którzy twierdzą, że surrealizm jest po prostu mizoginiczny czy antyfeministyczny" (Krauss 17). W pracy Bachelors [Kawalerowie] na temat dziewięciu artystek, w której Bellmer pojawia się obok Claude Cahun, Dory Maar i innych kobiet, Krauss omawia odbitkę żelatynowo-srebrną zdjęcia dwóch kobiecych nóg Dory Maar z 1936 r. I tłumaczy, że „efekt kompletnego zamazania na obrazie, który jest w większości idealnie ostry, wytwarza niejednoznaczność płci, która w efekcie ukazuje ciało-w-trakcieprzeróbki, projektowane przez falliczną kobietę" (Krauss 1999: 19). Poprzez nawiązanie do matki modliszki - która, jak zauważa Krauss, też jest po prostu parą nóg - tłumaczy kastracyjne i fetyszystyczne elementy tych zdjęć - cechy, które dostrzega również u Bellmera. Odrzucając zawężające odczytania surrealizmu, sugeruje, że zdjęcia lalki Bellmera, podobnie jak zdjęcia Maar i innych surrealistów, są dalekie od reifikowania patriarchalnych norm i wyrażają raczej głęboką ambiwalencję, która dekonstruuje stabilność męskiego ego, tak jak to już wcześniej robił de Sade. Należy podkreślić, że dla Krauss, Fostera i innych "ciało-w-trakcie-przeróbki" stanowi bezpośredni atak na pozorną spójność faszystowskiej podmiotowości.

Xavière Gauthier jest jedną z najwcześniejszych i najbardziej przenikliwych feministycznych interpretatorek Bellmera. Pisze ona, że "»Greedy Little Girls« [Zachłanne małe dziewczynki] Bellmera poddają się autosodomii, wyrażając ewidentną przyjemność i ból” a następnie stwierdza, że "lalka, 
którą tradycyjnie daje się małym dziewczynkom, by im pomóc w przygotowywaniu się do roli matki, jest poszatkowana w sadystyczny sposób, a następnie ustawiona w wyzywającej pozie" (Gauthier 1971: 25-26). Ale krytykuje ona Bellmera tylko jako przedstawiciela surrealizmu jako takiego. Rozpoczynając i kończąc swą analizę Bellmerem, wykorzystuje jego konstrukcję „Artylerzystka w stanie łaski" jako emblematyczną dla stosunku surrealistów do seksu. Artylerzystka o wysokości około metra zbudowana jest z wymiennych części; jej pęknięta głowa bez twarzy i amalgamat elementów mechanicznych i quasi-ludzkich przypomina jednocześnie kobiece ciało, maszynę i modliszkę (Rys. 5). Gauthier pisała, że "surrealizm starał się wprowadzić karabin maszynowy do serca mieszczańskiego świata i przez dwadzieścia lat trzymać ten świat na celowniku" (Gauthier 1971: 23). Według niej, dla surrealistów seksualność i erotyzm nie stanowiły celów samych w sobie, tylko ulubioną broń do atakowania mieszczańskiego społeczeństwa. Subwersywna moc, której surrealiści dopatrują się w Erosie, w połączeniu z nadrzędnym celem wywracania wartości przede wszystkim seksualnych jest tym, co najbardziej odróżnia surrealizm od rewolucyjnego marksizmu, z którym jednak ma wiele wspólnego (Gauthier 1971: 36-38).

Taka, według Gauthier, jest nadzieja surrealizmu: „perwersja i jej współudział w destrukcji społeczeństwa" (Gauthier 1971: 48). To zainteresowanie destrukcyjną siłą Erosa, wyrażone najlepiej w postaci poetyckiej alegorii w Chants de Maldoror Lautréamonta, gdy Maldoror zawiera „pakt z Prostytucją, by siać zamęt w rodzinach" (36), przenika z symbolizmu do różnych akspektów dwudziestowiecznej awangardy, ale jest szczególnie widoczne w surrealizmie. Wywodząca się od de Sade'a idea "perwersji i jej współudział w destrukcji społeczeństwa” tworzy jeżeli nie tradycję, to nadzieję, która znajduje swój największy potencjał dekonstrukcyjny w systematyzacji myśli de Sade'a przez Bataille'a, Pierra Klossowskiego i innych. Gdy przyjrzymy się odczytaniom de Sade'a przez Klossowskiego i Bataille'a, eschatologiczna moc perwersji zaprzecza istnieniu jakiegokolwiek ludzkiego pierwiastka czy podstawy dla porządku społecznego poza Bogiem. Tę zdecydowanie nietzscheańską myśl rozwijali po wojnie między innymi Gilles Deleuze i Michel Foucault. Dla Klossowskiego to, co osiąga „intergralna potworność" u de Sade'a to likwidacja binarnego podziału płci na rzecz pojedynczej i perwersyjnej polimorficzności. Jak pisze:

Bezpośredni efekt integralnej potworności wymyślonej przez de Sade'a to doprowadzenie do wymiany specyficznych cech płci. Efekt ten nie polega na prostej symetrycznej zamianie schematu zróżnicowania w obrębie każdej z dwóch płci, z czynną i bierną pederastią z jednej strony i lesbianizmem i trybadyzmem $z$ drugiej. W integralnej potworności rozumianej jako projekt dydaktyczny na rzecz zmysłowej polimorficzności, dwoje przedstawicieli gatunku, mężczyzna i kobieta, przyjmą w obcowaniu ze sobą dwojaki model. Każda z dwóch płci uwewnętrznia ten dwojaki model nie tylko z uwagi na właściwą sobie ambiwalencję, ale również z powodu ornamentacji, w jaką Sade tę ambiwalencję przyozdabia. (Klossowski 1991: 35) 
U Bellmera Gauthier dostrzega to samo, co u de Sade'a. Jak pisze, "U Bellmera, tak jak u de Sade'a, traci się swoje ciało, [które] wkręca się w ciało drugie, tworząc coś w rodzaju androgyne (takie jak Juliette de Sade'a)" (Gauthier 1971: 57). Mimo iż Gauthier pozostaje sceptycznie nastawiona do tych koncepcji i wydaje się, że woli, by każda z płci utrzymywała się w opozycji do drugiej, jej spostrzeżenia pokazują, że nawet dla zdecydowanych krytyków sadystyczna przemoc Bellmera i de Sade's problematyzuje prostą opozycję płci.

Dlatego też, jeżeli Bellmer polega na fallicznym rejestrze, robi to całkowicie świadomie i samokrytycznie. Ciało-jako-anagram wyraża przynajmniej tyle: jest ono projektem erotycznym, który jest jednocześnie onanistyczny i oniryczny, lecz projekt ten ani nie ignoruje istnienia norm płci kulturowej, ani nie przemawia na rzecz ich utrzymania. Jeżeli, jak sugeruje Lacan, fallus jest znaczącym przeznaczonym do oznaczania efektów znaczenia w ogóle" (Lacan 2006: 579), to ciało-jako-anagram Bellmera sugeruje coś przeciwnego - „efekty znaczeniowe" poza rejestrem fallicznym. O ile, bowiem przez wyparcie i zakaz, przez sublimację i perwersję pożądanie i zasada przyjemności przechodzą przez ciało kondensując i nakładając się na język i świadomość, o tyle to właśnie w ciele, w tej tajemnicy seksualnej różnicy, zachodzą "efekty znaczeniowe”, a fallus zostaje podważony najbardziej bezpośrednio. Bellmer pokazuje nam to w swoim obrazie fallusa wyłaniającego się z sromu przedstawionego w Małej anatomii. Jak pisze, "Gdy już znajdę się zdrętwiały pod plisowaną spódnicą wszystkich twoich palców i zmęczę się rozplataniem wieńców owijających półsen twojego nienarodzonego owocu, wtedy tchniesz we mnie swój zapach i swoją gorączkę, by w pełnym świetle moja płeć wyłoniła się z twojej" (Bellmer 2004: 43-44). Oczywiście jest w tych słowach pewnego rodzaju przemoc. Lecz potępianie czy deprecjonowanie Bellmera z uwagi na tę przemoc jest trywializowaniem i ignorowaniem niezwykłego artysty, który jest trudny i tragiczny, to pewne, ale jako artysta zarówno podważa normy płci kulturowej, jak i je reifikuje. Uczucia, które wywołują w nas prace Bellmera należy odróżniać od siły tych uczuć; siła oddziaływania jego prac jest jedynym testamentem ich znaczenia. Trzeba to jasno powiedzieć: seksualność jest niebezpieczna. Stanowi trudność leżącą u podstaw nie tylko psychicznego „zdrowia”, ale także „patologii”. Bellmer pomaga nam zmierzyć się z tym niebezpieczeństwem. Chciałby nam uświadomić, że seksualność to Artylerzystka w stanie łaski: Nie tylko ją rżniesz! Ona cię pożre jak matka-modliszka po kopulacji!

\section{Bibliografia}

Bataille, Georges. 1986/2001. Eroticism. Tłum. M. Dalwood. London: Penguin Books.

Bellmer, Hans. 2004. Little Anatomy of the Unconscious, or The Anatomy of the Image. Tłum. J. Graham. Dominion, VT: Dominion Publishing.

- - - 2001. Memories of the Doll Theme. Tłum. P. Chametzky, Susan Felleman i Jochen Schindler. W: Therese Lichtenstein. Behind Closed Doors: The Art of Hans Bellmer. Berkeley: University of California Press. s. 169-174.

- - -. 2000. Notes on the Subject of the Ball Joint. W: (red.) Taylor, Sue. Hans Bellmer: The Anatomy of Anxiety. Cambridge: MIT Press. s. 212-218. 
Breton, André. 1969. Second Manifesto of Surrealism. W: Manifestos of Surrealism. Tłum. R. Seaver and H. R. Lane. Ann Arbor, MI: University of Michigan Press. s. 117-194.

Freud, Sigmund. 2005. Fetishism. The Unconscious. Tłum. G. Frankland. London: Penguin, s. 93-100.

Foster, Hal. 1991. Amor Fou. „October" 56. High/Low: Art and Mass Culture: s. 64-97.

- - -. 1993. Compulsive Beauty. Cambridge: MIT Press.

- - -. 2003. The Uncanny. W: The Uncanny. Tłum. D. McLintock. London: Penguin, s. 121-162.

- - -. 2006. Three Essays on Sexual Theory. W: The Psychology of Love. Tłum. S. Whiteside. London: Penguin, s. 111-220.

Gauthier, Xavière. 1971. Surréalisme et sexualité. Paris: Éditions Gallimard.

Kittelmann, Udo, Kyllikki Zacharias (red.). 2010. Hans Bellmer - Louise Bourgeois: Double Sexus. Berlin: Sammlung Scharf-Gerstenberg.

Klossowski, Pierre. 1991. Sade My Neighbour. Tłum. Alphonso Lingis. Evanston, Illinois: Northwestern University Press.

Krauss, Rosalind. 1999. Bachelors. Cambridge: MIT Press.

- - -. 1985. Corpus Delecti. „October" 33, s. 31-72.

Lacan, Jacques. 2006. The Signification of the Phallus. W: Écrits. Tłum. B. Fink. W. W. New York: Norton \& Company.

Lautréamont, Comte de. Maldoror and Poems. Tłum

. Paul Knight. London: Penguin Books, 1978.

Mahon, Alyce. 2005. Surrealism and the Politics of Eros, 1938-1968. London: Thames \& Hudson.

Peppiatt, Michael. 1973. Balthus, Klossowski, Bellmer: Three Approaches to the Flesh. „Art International", s. 23-28, 65.

Webb, Peter. 1975. The Erotic Arts. London: Secker \& Warburg.

- - -, Short, Robert. 2006. Death, Desire and the Doll: The Life and Art of Hans Bellmer. Los Angeles, CA: Solar Books. 